\title{
Polycythaemia: an unusual presentation of multiple myeloma
}

\author{
Elaine J Hutchison, ${ }^{1}$ Josephine A Taverna, ${ }^{1,2}$ Qi Yu, ${ }^{1}$ Andrew M Yeager ${ }^{1,2}$
}

${ }^{1}$ Department of Medicine, University of Arizona College of Medicine, Tucson, Arizona, USA

${ }^{2}$ University of Arizona Cancer Center, Tucson, Arizona, USA

\section{Correspondence to}

Professor Andrew M Yeager, ayeager@email.arizona.edu

Accepted 30 August 2016

\section{SUMMARY}

In contrast to anaemia, polycythaemia is a distinctly uncommon finding in patients with multiple myeloma. We describe the presence of otherwise unexplained polycythaemia in a 57-year-old Caucasian man who was found to have $\lg G \kappa$ multiple myeloma. After treatment of myeloma, the polycythaemia resolved. We reviewed previous reports of polycythaemia associated with multiple myeloma and discuss potential pathophysiological mechanisms that link these 2 conditions.

\section{BACKGROUND}

In addition to bone lesions, hypercalcaemia and renal dysfunction, anaemia is one of the hallmarks of multiple myeloma and is observed at diagnosis in $73 \%$ of patients. ${ }^{1}$ Indeed, a haemoglobin $\leq 12 \mathrm{~g} / \mathrm{dL}$ with either $\geq 10 \%$ clonal plasma cells on bone marrow biopsy or biopsy-proven plasmacytoma is sufficient for the diagnosis of multiple myeloma. ${ }^{2}$

In contrast, a very small number of patients with multiple myeloma may have polycythaemia, a somewhat counterintuitive association that was first described in $1949 .{ }^{3}$ Most of these reports included patients who had antecedent or concomitant polycythaemia vera (PV) or who already had secondary polycythaemia. The presence of otherwise unexplained polycythaemia around the time of diagnosis of multiple myeloma is extremely uncommon.

We describe a patient who presented with polycythaemia and was subsequently found to have multiple myeloma. The polycythaemia, for which no other aetiology was found, resolved after initiation of systemic treatment for myeloma. Additionally, we reviewed previous studies of polycythaemia associated with multiple myeloma and discuss the possible interactions between these two conditions.

\section{CASE PRESENTATION}

A 57-year-old Caucasian male had a haemoglobin level of $19.2 \mathrm{~g} / \mathrm{dL}$ and a haematocrit of $58.6 \%$ during routine health maintenance evaluation. He reported insidious onset of daytime fatigue, shortness of breath with exercising, recent intermittent headaches and self-limited episodes of epistaxis. His medical history was positive for hypertension that was well controlled on lisinopril, amlodipine, hydrochlorothiazide and spironolactone. He exercised vigorously and regularly, was a lifelong non-smoker, did not reside in a high-altitude location and denied night-time snoring. The patient denied use of prescribed or non-prescribed supplements, including testosterone and nutritional supplements. He did not have a family history of haematological diseases. His physical examination showed a blood pressure of $126 / 74 \mathrm{~mm} \mathrm{Hg}$, heart rate $62 \mathrm{bpm}$, oxygen saturation $96 \%$ on room air, body mass index $26 \mathrm{~kg} / \mathrm{m}^{2}$, normal respiratory effort, lungs clear to auscultation bilaterally, a II/VI systolic ejection murmur, no lymphadenopathy, no hepatosplenomegaly, and no telangiectases or other cutaneous abnormalities.

\section{INVESTIGATIONS}

The white cell count (WCC) was $9.0 \times 10^{9} / \mathrm{L}$, with normal differential WCC, platelets $235 \times 10^{9} / \mathrm{L}$, haemoglobin $18.9 \mathrm{~g} / \mathrm{dL}$ and haematocrit $54.5 \%$. Creatinine was slightly elevated at $1.53 \mathrm{mg} / \mathrm{dL}$ (patient's baseline creatinine was $1.1 \mathrm{mg} / \mathrm{dL}$ ), blood urea nitrogen was $25 \mathrm{mg} / \mathrm{dL}$, calcium $9.1 \mathrm{mg} / \mathrm{dL}$, total protein $9.1 \mathrm{mg} / \mathrm{dL}$ and albumin $3.6 \mathrm{mg} / \mathrm{dL}$. Urinalysis showed rare red blood cells and WCCs, but no protein, casts or crystals. Carboxyhaemoglobin was $0.5 \%$ (normally $<3 \%$ in non-smokers), haemoglobin electrophoresis showed haemoglobin AA2, and JAK2 mutation analysis was negative. Erythropoietin (EPO) was slightly increased at $32.4 \mathrm{mU} / \mathrm{mL}$ (normal range, 4.1-19.5). A polysomnographic sleep study was normal. Ultrasound scan of the abdomen revealed a single right renal cyst, but no solid lesions of the liver or kidney, and no perinephric fluid collections. Serum protein electrophoresis and immunofixation showed serum $M$ protein at $3.4 \mathrm{~g} / \mathrm{dL}$ and $\operatorname{IgG} \kappa$ monoclonal protein; serum IgG level was $4921 \mathrm{mg} / \mathrm{dL}$, free $\kappa$ light chains $192.25 \mathrm{mg} / \mathrm{L}$, free $\lambda$ light chains $5.61 \mathrm{mg} / \mathrm{L}$ and free $\kappa / \lambda$ light chain ratio 34.27 . Bone marrow biopsy revealed $30 \%$ cellularity with $9-15 \% \kappa$ light chainrestricted plasma cells. Marrow cytogenetics showed 46 , XY, but fluorescent in situ hybridisation (FISH) analysis showed $7.72 \%$ of nuclei with three copies of $5 \mathrm{p} 15.2,6.36 \%$ of nuclei with trisomy 9 and 3.64\% of nuclei with trisomy 15 . Radiographical skeletal survey showed diffuse degenerative changes in the spine but no discrete osteolytic lesions. Whole-body positron emission/computed tomographic scanning displayed patchy increased uptake in the pelvis and spine but no discrete fluorodeoxyglucose-avid lesions and no abnormal intracranial findings. The patient was diagnosed with IgG $\kappa$ multiple myeloma, Durie-Salmon stage IIA; as $\beta-2$ microglobulin level had not been obtained, International Scoring System (ISS) stage could not be determined.

\section{DIFFERENTIAL DIAGNOSIS}

The differential diagnosis of secondary polycythaemia is broad, but the most common aetiology is 
Figure 1 Levels of haemoglobin and serum monoclonal M-protein. Bor, bortezomib; Cy, cyclophosphamide; Dex, dexamethasone; Len, lenalidomide; PBSCT, peripheral blood stem cell transplant.

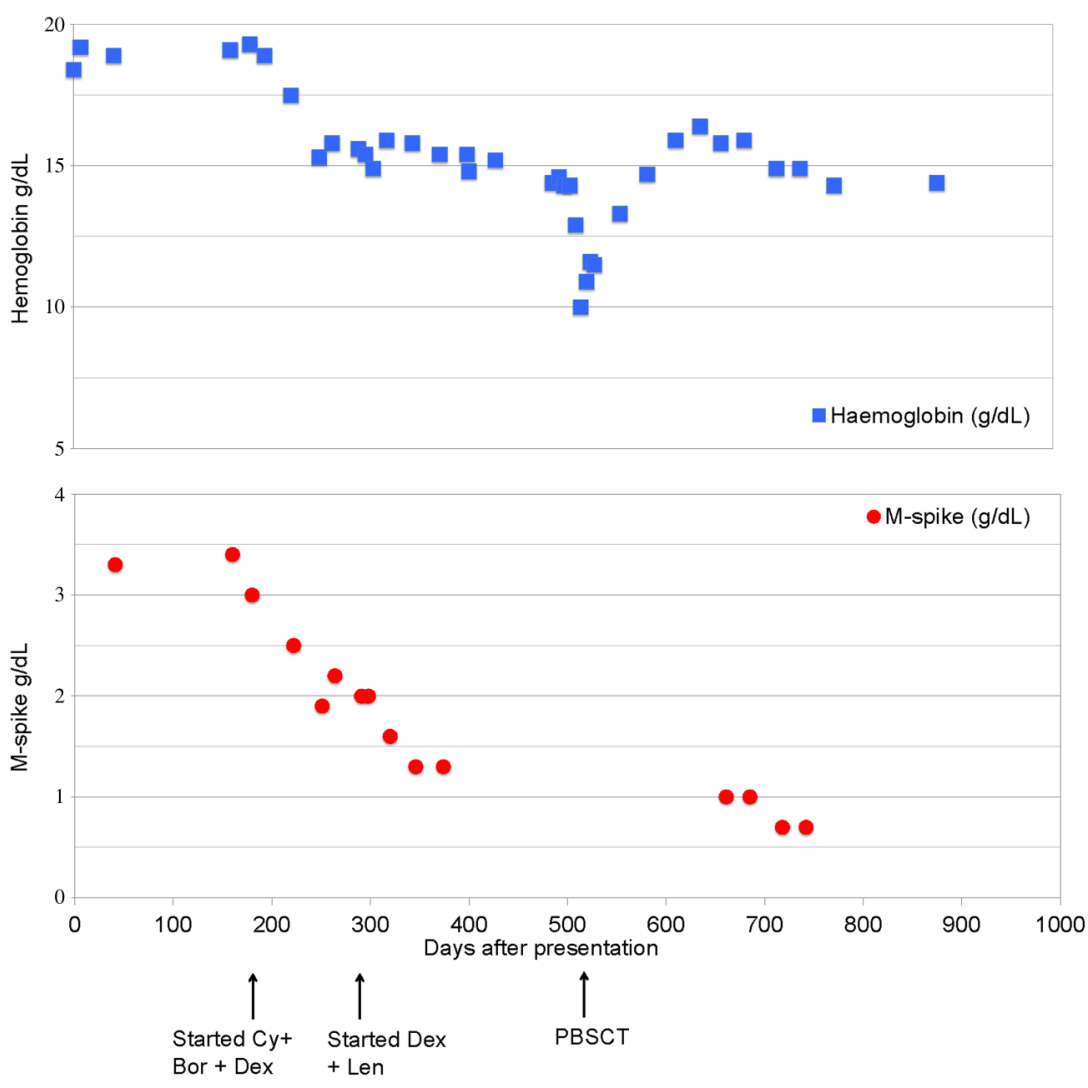

chronic hypoxia. Chronic hypoxia leading to secondary polycythaemia could result from tobacco use, living at high altitude, pulmonary diseases, haemoglobinopathies, carbon monoxide exposure and sleep apnoea, all of which were effectively ruled out in our patient. Polycythaemia from EPO-secreting tumours (eg, intracranial haemangioblastoma, hepatocellular carcinoma, renal cell carcinoma) was also excluded by imaging studies. Although decreased renal perfusion may be associated with polycythaemia, the patient's haemoglobin did not normalise despite adjustment of his antihypertensive regimen. Our comprehensive systematic evaluation did not identify a cause for secondary polycythaemia in this patient. We concluded that there was a likely association between the development of polycythaemia and the new diagnosis of multiple myeloma.

\section{TREATMENT}

The patient initially underwent phlebotomy to maintain a haematocrit below $47 \%$. He then received 4 months of treatment with cyclophosphamide, bortezomib and dexamethasone, which was discontinued because of a plateau in response and development of bortezomib-associated peripheral sensory neuropathy. He subsequently received a total of six cycles of lenalidomide ( $25 \mathrm{mg}$ orally for 21 of 28 days) and dexamethasone, after which his myeloma had attained a first partial response (PR), with serum IgG 1316 and serum M protein $0.7 \mathrm{~g} / \mathrm{dL}$. Following a preparative regimen of melphalan, the patient underwent autologous peripheral blood stem cell transplant (PBSCT) in first PR. He then received post-PBSCT maintenance lenalidomide, on which he remains.

\section{OUTCOME AND FOLLOW-UP}

Following initial treatment for myeloma, our patient's haemoglobin stabilised at $14.3-15.9 \mathrm{~g} / \mathrm{dL}$ and was $14.4 \mathrm{~g} / \mathrm{dL}$ at 1 year after PBSCT (figure 1). At his 1-year post-transplant evaluation, serum $\mathrm{M}$ protein was $0.5 \mathrm{~g} / \mathrm{dL}$, and bone marrow biopsy showed $5-10 \%$ persistent $\kappa$ light chain-restricted plasma cells, consistent with ongoing PR.

\section{DISCUSSION}

Polycythaemia associated with multiple myeloma is rare, with 26 cases reported over the past 70 years. Concomitant or antecedent PV occurred in 21 of those cases, with a median interval of 2 years (range, 0-21 years) between diagnoses of PV and myeloma. ${ }^{3-14}$ However, only four patients with otherwise unexplained polycythaemia and myeloma have been reported (table 1). ${ }^{10}$ 15-18 In three of those patients, polycythaemia preceded the diagnosis of myeloma by 8 months to 8 years. ${ }^{101516}$ Only one patient had the concomitant diagnoses of polycythaemia of unknown aetiology and myeloma, as was the case with the patient described in our report. In that patient, as in ours, concomitant polycythaemia resolved after initiation of therapy for myeloma. ${ }^{17} 18$

The uncommon simultaneous occurrence of polycythaemia and myeloma, and the resolution of polycythaemia with myeloma treatment, suggest a link between these two seemingly paradoxical disorders. Several mechanisms could explain the association between polycythaemia and myeloma. Overt or subclinical renal injury from monoclonal light chains in the renal tubules could lead to local hypoxia and increased EPO production. ${ }^{18}$ Of note, both elevated ${ }^{19}$ and decreased ${ }^{20}$ levels of EPO, relative to degrees of anaemia and renal insufficiency, have been reported in patients with myeloma. The constitutive production of EPO by neoplastic cells (tumour polycythaemia) has been described in renal cell carcinoma, hepatocellular carcinoma, uterine leiomyoma, hemangioblastoma and pheochromocytoma; ${ }^{21}$ as malignant plasma cells do not produce EPO, this mechanism is not likely in polycythaemia-associated myeloma. The recently-described TEMPI syndrome (telangiectases, erythrocytosis with elevated EPO, monoclonal gammopathy, 
Table 1 Reported cases of multiple myeloma associated with otherwise unexplained polycythaemia

\begin{tabular}{|c|c|c|c|c|c|c|}
\hline $\begin{array}{l}\text { Case } \\
\text { number }\end{array}$ & $\begin{array}{l}\text { Age/ } \\
\text { gender }\end{array}$ & Initial diagnosis/diagnoses & $\begin{array}{l}\text { Initial } \\
\text { treatment }\end{array}$ & $\begin{array}{l}\text { Time to diagnosis of } \\
\text { myeloma }\end{array}$ & Myeloma treatment(s) & Reference \\
\hline 1 & $62 / \mathrm{M}$ & Polycythaemia & Phlebotomy & 6 years & Monitoring & 10 \\
\hline 2 & $58 / \mathrm{M}$ & Polycythaemia & Phlebotomy & 8 years & Not reported & 15 \\
\hline 3 & $76 / \mathrm{M}$ & $\begin{array}{l}\text { Polycythaemia (idiopathic } \\
\text { erythrocytosis) }\end{array}$ & Phlebotomy & 8 months & Unknown (lost to follow-up) & 16 \\
\hline 4 & $55 / \mathrm{M}$ & $\begin{array}{l}\text { Simultaneous polycythaemia } \\
\text { and myeloma }\end{array}$ & Phlebotomy & - & $\begin{array}{l}\text { Vcr/Dox/Dex } \times 2 \text {, high-dose Dex } \times 2, \text { PBSCT, PBSCT } \\
\text { after relapse, Bor/Dex, Mel/Pred/Thal }\end{array}$ & 1718 \\
\hline 5 & $56 / \mathrm{M}$ & $\begin{array}{l}\text { Simultaneous polycythaemia } \\
\text { and myeloma }\end{array}$ & Phlebotomy & - & Cy/Bor/Dex, Len/Dex, PBSCT, Len maintenance & $\begin{array}{l}\text { Present } \\
\text { report }\end{array}$ \\
\hline
\end{tabular}

Bor, bortezomib; Cy, cyclophosphamide; Dex, dexamethasone; Dox, doxorubicin; Len, lenalidomide; Mel, melphalan; PBSCT, peripheral blood stem cell transplant; Pred, prednisone; Thal, thalidomide; Vcr, vincristine.

perinephric fluid collection and intrapulmonary shunt) may provide clues to a common pathogenesis of polycythaemia and myeloma. ${ }^{22}$ Although patients with this rare paraneoplastic syndrome have only been described as having monoclonal gammopathy of undetermined significance (MGUS) $)^{22-27}$ or

\section{Patient's perspective}

- I was frustrated in my efforts to research and make sense of my dual diagnoses of polycythaemia and myeloma nearly 3 years ago. My trusted physicians could not offer much explanation either. So I was very glad to review a manuscript of this article, which offers helpful perspective on my unusual case. I hope its publication will benefit others.

With full awareness that this is far from 'scientific', I offer the following take: I suspect I had a smouldering condition or monoclonal gammopathy of undetermined significance for several years, releasing light chains that caused kidney stress contributing to hypertension. My habit of vigorous weekly hikes in the desert hills from 3500 to 9000 feet elevation may have sometimes left me dehydrated and low on oxygen. Perhaps my elevated blood cell production was a unique physiological response to this combination of factors.

- I attributed early symptoms-headache, daytime fatigue-to overmedication and I pressed my internist on this point. When I reported daily nosebleeds, shortness of breath and an unusual incident of fatigue on the mountain trail, he ordered complete blood count that led me to the haematologist's office.

- It was remarkable that all signs of polycythaemia disappeared following phlebotomies and a few weeks of treatments with cyclophosphamide, bortezomib, and dexamethasone. At the same time, my kidney function improved markedly - a relief on its own, but also a strategic advantage, since it rendered me eligible for alternative treatment with lenalidomide. In turn, this course of treatment helped me reach eligibility for an autologous stem cell transplant, which has surely extended my life.

- As a postscript, it is remarkable that since completing the stem cell procedure my hypertension has mostly resolvedthis despite a less vigorous exercise regimen. While I still take a daily $50 \mathrm{mg}$ atenolol, my typical blood pressures are in the neighbourhood of $118 / 76 \mathrm{~mm} \mathrm{Hg}$. I cannot help but wonder, could this side benefit also corroborate my theory? smouldering myeloma, ${ }^{28}$ treatment of TEMPI syndrome with the proteasome inhibitor bortezomib reduced the levels of monoclonal protein and also led to decrease in levels of haemoglobin and EPO, improvement in telangiectatic lesions and perinephric fluid collections, and improvement in oxygenation of arterial blood. $^{22} 2427-29$

The marked improvement observed after bortezomib treatment in patients with TEMPI syndrome suggests a central pathogenic role of $\mathrm{M}$ protein. Bortezomib inhibits hypoxia-inducible factor- $1 \alpha$ (HIF-1 $\alpha$ ), a key transcription factor in the oxygensensing pathway responsible for EPO secretion, ${ }^{30}$ which may explain its efficacy in reducing EPO and erythrocytosis in TEMPI. In addition, the marked improvement in secondary erythrocytosis after autologous PBSCT in a patient with TEMPI syndrome also suggests that secondary erythrocytosis may be a paraneoplastic phenomenon of plasma cell dyscrasias. ${ }^{31}$

It remains unclear why our patient developed concurrent polycythaemia and multiple myeloma. His subacute kidney injury, combined with diuretic use, is one explanation, and the resolution of polycythaemia with initiation of myeloma treatment might have resulted from decreased presence of monoclonal light chains in the renal tubules. Our patient did not meet criteria for TEMPI syndrome, as he had no telangiectases, perinephric fluid collections or findings suggestive of intrapulmonary shunt. He did have a slight elevation in serum EPO level, and one might hypothesise that, as in TEMPI syndrome, his polycythaemia resulted from $\mathrm{M}$ protein increasing the function of HIF- $1 \alpha$ and increased EPO production. Tumour polycythaemia as a result of exogenous production of EPO by myeloma cells is highly unlikely. Further study of the pathogenesis of TEMPI syndrome may elucidate a link between multiple myeloma and polycythaemia.

\section{Learning points}

- Multiple myeloma commonly presents as anaemia, but in rare cases may be associated with otherwise unexplained polycythaemia.

- Secondary polycythaemia has a broad differential diagnosis including chronic hypoxia, reduced renal perfusion and chronic kidney disease and paraneoplastic secretion of erythropoietin (EPO) by neoplasms.

- Polycythaemia associated with multiple myeloma may result from myeloma-associated kidney disease, paraneoplastic EPO production, or direct action of the monoclonal protein on the oxygen-sensing pathway responsible for EPO secretion. 
Contributors EJH and JAT drafted the manuscript. All authors contributed to planning and revising the manuscript. AMY is responsible for the overall content as guarantor.

Funding National Cancer Institute (grant number P30 CA023074).

Competing interests None declared.

Patient consent Obtained.

Provenance and peer review Not commissioned; externally peer reviewed.

\section{REFERENCES}

1 Kyle RA, Gertz MA, Witzig TE, et al. Review of 1027 patients with newly diagnosed multiple myeloma. Mayo Clin Proc 2003;78:21-33.

2 Rajkumar SV, Dimopoulos MA, Palumbo A, et al. International myeloma working group updated criteria for the diagnosis of multiple myeloma. Lancet Oncol 2014;15:e538-48.

3 Lawrence JH, Rosenthal RL. Multiple myeloma associated with polycythemia; report of four cases. Am J Med Sci 1949;218:149-54.

4 Brody JI, Beizer LH, Schwartz S. Multiple myeloma and the myeloproliferative syndromes. Am J Med 1964;36:315-19.

5 Fink L, Bauer F, Perry JJ. Coincidental polycythemia vera and multiple myeloma: case report and review. Am J Hematol 1993;44:196-200.

6 Franzén S, Johansson B, Kaigas M. Primary polycythaemia associated with multiple myeloma. Acta Med Scand 1966;179:336-43.

7 Giertsen JC. Polycythaemia vera with multiple myeloma: report of a case. Acta Pathol Microbiol Scand 1956;38:439-46.

8 Heinle EW Jr, Sarasti HO, Garcia D, et al. Polycythemia vera associated with lymphomatous diseases and myeloma. Arch Int Med 1966:118:351-5.

9 Hill GC. Polycythemia and quadriplegia in multiple myeloma. A case report. Ohio State Med J 1963:59:1005-8.

10 Maeda K, Abraham J. Polycythemia associated with myeloma. Am I Clin Pathol 1984:82:501-5.

11 Malhotra J, Kremyanskaya M, Schorr E, et al. Coexistence of myeloproliferative neoplasm and plasma-cell dyscrasia. Clin Lymphoma Myeloma Leuk 2014;14:31-6.

12 Polnikorn N, Harisadangkul V, Srichaikul T. Polycythemia vera associated with multiple myeloma: report of a case. J Med Assoc Thai 1976;59:183-7.

13 Terpstra WE, Meuwissen OJ, Hagemeijer A, et al. Multiple myeloma and acute megakaryoblast leukemia in spent phase polycythemia vera. Am J Clin Pathol 1990:94:786-90

14 West WO. Multiple myeloma on polycythemia vera following radioactive phosphorus therapy. South Med J 1976;69:1516-17.
15 Inase N, Shichiri M, Marumo F. Secondary polycythemia associated with multiple myeloma. Jpn J Med 1989;28:396-8.

16 Chang H, Shih LY. Concurrence of multiple myeloma and idiopathic erythrocytosis. Acta Clin Belg 2009:64:434-5.

17 Lee SG, Lim G, Cho SY, et al. JAK2 mutation-negative secondary erythrocytosis in smoldering plasma cell myeloma: a case study and review of the literature. Acta Haematol 2011;126:169-71.

18 Yoon HJ, Baek SK, Lee WI, et al. JAK2 mutation-negative secondary erythrocytosis in multiple myeloma: a case report follow up. Exp Hematol 2013;41:S46.

19 Nielsen OJ, Brandt M, Drivsholm A. The secretory erythropoietin response in patients with multiple myeloma and Waldenström's macroglobulinaemia. Scand J Clin Lab Invest 1990:50:697-703.

20 Beguin $\mathrm{Y}$, Yerna $\mathrm{M}$, Loo $\mathrm{M}$, et al. Erythropoiesis in multiple myeloma: defective red cell production due to inappropriate erythropoietin production. $\mathrm{Br} J \mathrm{Haematol}$ 1992;82:648-53.

21 Staszewski H. Hematological paraneoplastic syndromes. Semin Oncol 1997;24:329-33.

22 Sykes DB, Schroyens W, O'Connell C. The TEMPI syndrome-a novel multisystem disease. N Engl J Med 2011;365:475-7.

23 Bazari H, Attar EC, Dahl DM, et al. Case records of the Massachusetts General Hospital. Case 23-2010. A 49-year-old man with erythrocytosis, perinephric fluid collections, and renal failure. N Eng/ I Med 2010;363:463-75.

24 Ryden $A$, Wei $K$, Rodriguez $R$, et al. Too much blood: a case of the newly described TEMPI syndrome. Chest 2013;144:927A.

25 Viglietti D, Sverzut JM, Peraldi MN. Perirenal fluid collections and monoclonal gammopathy. Nephrol Dial Transplant 2012;27:448-9.

26 Olerud JE, Robertson HT, Hossack KF, et al. A patient with polycythemia. West J Med 1981;135:375-82.

27 Mohammadi F, Wolverson MK, Bastani B. A new case of TEMPI syndrome. Clin Kidney J 2012;5:556-8.

28 Kwok M, Korde N, Landgren O. Bortezomib to treat the TEMPI syndrome. N Engl J Med 2012:366:1843-5.

29 Jasim S, Mahmud G, Bastani B, et al. Subcutaneous bortezomib for treatment of TEMPI syndrome. Clin Lymphoma Myeloma Leuk 2014;14:e221-3.

30 Shin DH, Chun YS, Lee DS, et al. Bortezomib inhibits tumor adaptation to hypoxia by stimulating the $\mathrm{FlH}$-mediated repression of hypoxia-inducible factor-1. Blood 2008;111:3131-6.

31 Kenderian SS, Rosado FG, Sykes DB, et al. Long-term complete clinical and hematological responses of the TEMPI syndrome after autologous stem cell transplantation. Leukemia 2015;29:2414-16.

Copyright 2016 BMJ Publishing Group. All rights reserved. For permission to reuse any of this content visit http://group.bmj.com/group/rights-licensing/permissions.

BMJ Case Report Fellows may re-use this article for personal use and teaching without any further permission.

Become a Fellow of BMJ Case Reports today and you can:

- Submit as many cases as you like

- Enjoy fast sympathetic peer review and rapid publication of accepted articles

- Access all the published articles

- Re-use any of the published material for personal use and teaching without further permission

For information on Institutional Fellowships contact consortiasales@bmjgroup.com

Visit casereports.bmj.com for more articles like this and to become a Fellow 